\title{
Validade da prova calórica monotermal em comparação à estimulação bitermal ${ }^{* * * * * * *}$
}

\author{
Validity of the monothermal caloric testing when compared to \\ bithermal stimulation
}

\author{
Luciana Cristina Matos Cunha* \\ Lilian Felipe** \\ Sarah Araújo Carvalho*** \\ Ludimila Labanca**** \\ Maurício Campelo Tavares***** \\ Denise Utsch Gonçalves******
}

*Fonoaudióloga. Mestranda do Programa de Pós-Graduação em Ciências da Saúde: Infectologia e Medicina Tropical da Universidade Federal de Minas Gerais (UFMG). Endereço para correspondência: Av. Professor Alfredo Balena, 190 Belo Horizonte - MG - CEP 30130-160 (deniseg@medicina.ufmg.br).

**Fonoaudióloga. Doutoranda do Programa de Pós-Graduação em Ciências da Saúde: Infectologia e Medicina Tropical da UFMG Professora Substituta do Curso de Fonoaudiologia da UFMG.

***Fonoaudióloga. Mestre em Saúde Pública pelo Programa de PósGraduação em Saúde Pública da UFMG.

****Graduanda em Fonoaudiologia pela UFMG.

*****Engenheiro. Doutor em Engenharia Elétrica com Ênfase em Engenharia Biomédica pela Universidade Federal de Santa Catarina. Professor do Curso de Engenharia da Universidade Católica de Pelotas.

******Médica Otorrinolaringologista. Professora Adjunto do Departamento de Oftalmologia e Otorrinolaringologia da Faculdade de Medicina da UFMG.

********Trabalho Realizado no Serviço de Otoneurologia do Hospital das Clínicas da UFMG

Artigo Original de Pesquisa

Artigo Submetido a Avaliação por Pares

Conflito de Interesse: não

Recebido em 08.08.2008.

Revisado em 20.12.2008; 10.02.2009; 23.12.2009.

Aceito para Publicação em 01.02.2010.

\begin{abstract}
Background: the use of monothermal caloric testing as a screening tool for vestibular asymmetry has been considered as an alternative to bithermal caloric testing. Aim: to evaluate the effectiveness of monothermal stimulation when compared to bithermal stimulation in the diagnosis of labyrinth asymmetry. Method: the results of 389 vectoelectronystagmography, performed between 1998 and 2007, were analyzed. Monothermal stimulation at $30 \mathrm{oC}$ and $44^{\circ} \mathrm{C}$ with unilateral weakness (UW) cut-off at $20 \%$ and $25 \%$ was compared to bithermal stimulation with cut-off at $25 \%$ (gold standard). The analysis was aimed at finding which kind of monothermal caloric test $(30 \mathrm{oC}$ or $44 \mathrm{oC})$ and which kind of cut-off $(20 \%$ or $25 \%)$ presented the highest specificity and sensitivity values in comparison with bithermal caloric testing. Results: sensitivity and specificity of monothermal caloric tests were: $84 \%$ and $80 \%$, at $30^{\circ} \mathrm{C}$ with UW at $20 \%$; $78 \%$ and $90 \%$, at $30^{\circ} \mathrm{C}$ with UW at $25 \% ; 81 \%$ and $78 \%$, at $44^{\circ} \mathrm{C}$ with UW at $20 \%$; $76 \%$ and $85 \%$, at $44^{\circ} \mathrm{C}$ with UW at $25 \%$. Conclusion: monothermal caloric testing with $30^{\circ} \mathrm{C}$ stimulus presented the highest sensibility and specificity values in comparison to the results obtained with bithermal stimulation. However, no significant difference was observed between such values and those obtained with $44^{\circ} \mathrm{C}$ stimulus. In all of the analyses, monothermal testing presented low sensitivity. Thus, the abnormal result of bithermal caloric testing might be seen as normal in monothermal stimulation. The use of monothermal testing as a screening tool is better recommended for individuals whose medical history suggests a low probability of vestibular disease.
\end{abstract}

Key Words: Electronystagmography; Caloric Tests; Dizziness.

\section{Resumo}

Tema: a estimulação calórica monotermal tem sido considerada como alternativa à prova calórica bitermal para triagem das assimetrias vestibulares. Objetivo: avaliar a confiabilidade da estimulação monotermal em relação à bitermal para o diagnóstico das assimetrias labirínticas. Método: avaliaram-se 389 resultados de vectoelectronistagmografia realizados entre 1998 e 2007. A estimulação monotermal de $30^{\circ} \mathrm{C}$ e $44^{\circ} \mathrm{C}$ com pontos de corte de predomínio labiríntico (PL) em $20 \%$ e em $25 \%$ foi comparada à bitermal com ponto de corte em $25 \%$ (padrão ouro). Na análise, interessou encontrar qual foi à prova monotemal $\left(30^{\circ} \mathrm{C}\right.$ ou $\left.44^{\circ} \mathrm{C}\right)$ e com qual ponto de corte $(20 \%$ ou $25 \%)$ que apresentou os valores mais elevados de sensibilidade e especificidade quando comparada à prova bitermal. Resultados: a sensibilidade e especificidade da prova monotermal foram respectivamente de: $84 \%$ e $80 \%$, a $30^{\circ} \mathrm{C}$ com PL em $20 \%$; $78 \%$ e $90 \%$, a $30^{\circ} \mathrm{C}$ com PL em $25 \%$; $81 \%$ e $78 \%$, a $44^{\circ} \mathrm{C}$ com PL em $20 \%$; $76 \%$ e $85 \%$, a $44^{\circ} \mathrm{C}$ com PL em $25 \%$. Conclusão: a prova monotermal com estimulo a $30^{\circ} \mathrm{C}$ apresentou valores mais elevados de sensibilidade e especificidade quando comparada a bitermal. Contudo, não se observou diferença significativa em relação aos valores observados com estímulo a $44^{\circ} \mathrm{C}$. Em todas as análises, a prova monotermal apresentou a limitação da baixa sensibilidade, de modo que testes alterados pela bitermal podem passar como normais pela prova monoternal. Ao se decidir pela realização da prova monotermal como triagem, deve-se realizá-la em indivíduos com menor probabilidade de estar com doença vestibular, a partir da história clínica.

Palavras-Chave: Eletronistagmografia; Testes Calóricos; Tontura.

Referenciar este material como:

$\Omega$ Cunha LCM, Felipe L, Carvalho SA, Labanca L, Tavares MC, Gonçalves DU. Validity of the monothermal caloric testing when compared to bithermal stimulation (original

$\sum 3$ title: Validade da prova calórica monotermal em comparação à estimulação bitermal). Pró-Fono Revista de Atualização Científica. 2010 jan-mar;22(1):67-70. 


\section{Introduction}

The caloric test is considered an important stage of vectoeletronistagmography (VENG), for it offers an accurate measure of vestibular function1. The most commonly used type is the bithermal caloric test (BCT), which involves stimulations by water irrigations in cold $\left(30^{\circ} \mathrm{C}\right)$ and warm $\left(44^{\circ} \mathrm{C}\right)$ temperature in each side separately2.

The monothermal test, first described by Torok (1969)3, is based on vestibular answers from water stimulation at the same temperature. This technique was suggested as an alternative to the BCT, with the same accuracy in the diagnosis of vestibular conditions, while diminishing the time spent and patient discomfort4-5.

However, researches on the effectiveness of the monothermal stimulation showed varied results with low specificity and high rates of false-negative results6-8. Such variability interferes with the reliability of the monothermal test and is justified, among other reasons, by the difference in cut-off values of unilateral weakness (UW) used in the studies.

Nowadays, there are few studies which propose to clarify the accuracy of monothermal stimulation in vestibular diagnosis. It is interesting to evaluate the validity of this test with the monothermal stimulation for the triage of vestibular disease.

The objective of this study was to verify the validity of monothermal tests compared to the bithermal tests, considering the different values for normal unilateral weakness in the monothermal caloric proof.

\section{Method}

This study was analysed and aproved by the Ethic Commitee in Research of The Federal University of Minas Gerais.

It was evaluated the results obtained with the selection randomly made of medical records of 387 medical examinations, referring to 103 male patients and 284 female patients, examined at Ambulatório de Otoneurologia do Hospital das Clínicas da UFMG from 1998 to 2007. The age of the subjects varied between 18 and 91 years old, with an average of 51 years old and standard deviation of 17 years.

It was included the subjects that had complete data of the caloric stimulation acomplished and excluded those that showed vestibular arreflexia and were suspected to have central alterations (oculamotor movements alteration, absence of the ocular fixation inhibitor effect and nystogmoghraphic inversion to bithermal stimulation). In addition, we excluded patients younger than 18 years.
The caloric testing was done through stimulations with water at temperature of $44^{\circ} \mathrm{C}$ and $30^{\circ} \mathrm{C}$, using a vectoelectronystagmograph with four channels (Contornic, versão SCV 5.1, Brazil).

During the nystagmus register, the patient stayed in supine position, with the head at $30^{\circ}$ for the maximum stimulation of the semicircular lateral channels. The caloric testing was done as follows: right side $44^{\circ} \mathrm{C}$, left side $44^{\circ} \mathrm{C}$, right side $30^{\circ} \mathrm{C}$ and left side $30^{\circ} \mathrm{C}$.

In order to interpret the bithermal caloric testing and the calculation of the unilateral weakness (UW), a formula proposed by Jongkess was used9. The monothermal answers were calculated using the following formula10:

$$
\begin{aligned}
& \mathrm{UW}=\text { Right } 44^{\circ} \mathrm{C}-\text { left } 44^{\circ} \mathrm{C} \times 100 \\
& \text { Right } 44^{\circ} \mathrm{C}+\text { left } 44^{\circ} \mathrm{C} \times 100
\end{aligned}
$$

A similar formula was applied to the monothermal stimulation at $30^{\circ} \mathrm{C}$.

In bithermal caloric testing, the levels of normality in absolute angular velocity values of slow component (VACL) was from $3^{\circ} \mathrm{C}$ to $50^{\circ} \mathrm{C} 11$. Related to the UW values, the value inferior to $25 \%$ (cut-off) was considered as normal in the bithermal caloric testing (gold standard) 17.

The results obtained through the bithermal caloric testing were grouped in two categories: symmetric (normal tests or bilateral hyporeflexia or hyperreflexia) and assymmetric (hyporeflexia or hyperreflexia with unilateral labyrinthic domain). These results were compared to the monothermal answers $\left(30^{\circ} \mathrm{C}\right.$ or $\left.44^{\circ} \mathrm{C}\right)$ with unilateral weakness (UW) cut-off at $20 \% 7$ and $25 \%$.

The program Epi-Info 3.4.2 was used for the data entry and the program Stata 9.2 for the calculation of the sensitivity and specificity, considering the bithermal caloric testing as the gold standard testing.

\section{Results}

From the 387 evaluated subjects, the bithermal caloric testing identified 322 medical examinations with normal UW and 65 with altered UW.

Comparing the results of monothermal stimulation at $30^{\circ} \mathrm{C}$ with those of the bithermal one, from the 322 medical examinations identified as normal by the bithermal testing, 62 were seen as altered with cut-off to the UW at $2 \%$ and 33 to the UW at 25\%. From the 65 medical examinations identified as altered by the bithermal testing, 10 were seen as normal by the monothermal testing with cut-off to the UW at $20 \%$ and 14 to the UW at 25\%. 
Comparing the results of the monothermal stimulation at $44^{\circ} \mathrm{C}$ with those of the bithermal, from the 322 medical examinations identified as normal by the bithermal testing, 72 were seen as altered with cut-off to the UW at $20 \%$ and 49 to the UW at 25\%. From the 65 medical examinations identidied as altered by the bithermal testing, 12 were seen as normal by the monothermal with cut-off to the UW at $20 \%$ and 15 to the UW at $25 \%$.

The comparative values of sensitivity and specificity to both stimulations with different cutoffs are described in table 1.

TABLE 1 . Comparison of the monothermal testing at temperatures of $30^{\circ} \mathrm{C}$ and $44^{\circ} \mathrm{C}$ with cut-offs at $20 \%$ and $25 \%$ in relation to the the bithermal testing with cut-off at 25\% (gold standard).

NORMALITY CUT-OFF VALUE FOR UNILATERAL WEAKNESS CONSIDERED IN MONOTHERMAL CALORIC TESTING

Stimulus temperature at $30^{\circ} \mathrm{C}$

$20 \%$

$25 \%$

$20 \%$

$25 \%$

\section{SENSITIVITY SPECIFICITY}

$78 \%(51 / 65)$

Stimulus temperature at $44^{\circ} \mathrm{C}$

$82 \%(53 / 65) \quad 78 \%$

(250/322)

$77 \%(50 / 65)$
$85 \%$

$(273 / 322)$

\section{Discussion}

The monothermal caloric testing is considered as a screening tool in vestibular asymmetry research. When in doubt about the result, the bithermal stimulation must be used10, 14-15. It is known that the objective of any screening tool testing is to be trustful to the ordinary results (greater sensitivity). This reasoning is true for testings that are used as screening tools for infections dieases or postnatal hearing16.
In this study, the results indicated that the trustfulness of the answers demonstrated by the monothermal caloric testing had little variation when the stimulation temperature was at $30^{\circ} \mathrm{C}$ or at $44^{\circ} \mathrm{C}$. On the other hand, when the value of the UW was altered from $20 \%$ to $25 \%$, a diminishing in the sensitivity rates and na increasing in the specificity were observed. These results agree with the ones 
found by Jacobsob et al (1995)14, when they varied the normality value of UW from $24,5 \%$ to $29 \%$ in the monothermal caloric testing at $44 \%$. In fact, the greater the cut-off of the UW, the greatest the trustfulness of the altered results (greatest specificity). However, the probablility that medical examinations in patients with vestibular diseases that cause minor assymetries are considered normal is also greater (smaller sensitivity). Some examples would be vestibular diseases that don't cause significant vestibular assymetry. In this context, the cut-off of the UW at 20\% (and not at 25\%) would be considering a greater sensitivity and a smaller risk of considering as normal, medical examinations which would, in fact, be altered. However, even the UW cut-off at $20 \%$ is not enough to offer total trustflness in the ordinary result, because the greatest observed sensitivity was at $86 \%$ (table 1 ).

In general, the specificity of the monothermal testings obtained in this study to the stimulation at $30^{\circ} \mathrm{C}$ aand at $44^{\circ} \mathrm{C}$ was satisfactory, mainly when using the normality cut-off of the UW at $25 \%$ as can be seen in table 1 . This demonstrates taht the altered results from the monothermal testing are generally confirmed by the bithermal testing (greater specificity). On the other hand, analysing the sensitivity, the UW normality cut-off at $25 \%$ would be associated to a greater risk os non-diagnosis (smaller sensitivity). The bilateral vestibular damage caused by the use of drugs toxic to the vestibule such as gentamicin, the frequent use in medicine of aminoglycoside antibiotics, is a typical example of vestibular lesion with UW normal results in caloric testing17-18. In this case, the clinical history and the absolute values of the caloric answer, with bilateral hyporeflexia or areflexia would clarify the diagnosis.

\section{References}

1. Chawla N, Olshaker JS. Diagnosis and management of dizziness and vertigo. Emerg Med Clin North Am. 2006;90(2):291-304.

2. Fitzgerald G, Hallpike CS. Studies in human vestibular function I: Observations on the directional preponderance ("nystagmusbereitschaft") of caloric nystagmus resulting from cerebral lesions. Brain. 1942;62(2):115-37

3. Torok N. Differential caloric stimulations in vestibular diagnosis. Arch Otolaryngol. 1969;90(1):52-7.
In relation to the directional domain (PD), this study did not focus in tihs kind of evaluation parameter, once its clinical meaning hás been controversial. According to studies, PD alterations can be sbserved in central, peripheral or even in normal subjects20-24. Furthermore, the PD does not represent evidence of assymetry of the vestibular system as the UW represents and does not have values to spot the place of the lesion21-24.

Based on the results of this study, the use of monothermal caloric testing as screening tool is not recommended in clinical routine with patients suspected of having vestibular disease, in agreement to other investigations8,14-15,19. Even considering the patient's comfort and the little time to applying the test, the low sensitivity seen to all cut-off values evaluated in the study could make the validity of monothermal testing doubtful, considering as normal, subjects with labyrinthic disease that causes little assymetry. Thus, whenever possible, using the monothermal testing should be avoided. When necessary, it should be preferably used with a caloric stimlation at $30^{\circ} \mathrm{C}$ and normality UW value up to $20 \%$. This cut-off offers more satisfactory sensitivity rates, making the testing more trustful to establish the absence of vestibular disease.

\section{Conclusion}

To be considered a screening tool testing, the monothermal caloric testing, with stimulation in cold and hot temperatur, showed low sensitivity value, no matter the UW cut-off used. So, vestibular testing considered alterd in the bithermal caloric testing would pass as normal in the monothermal testing. Despite these limitations, from the clinical history and age of the patients, the monothermal stimulation could be applicable in subjects that are less prone to suffer from vestibular disease.
4. Longridge NS, Leatherdale A. Caloric screening tests. J Otolaryngol. 1980;9(6):478-81.

5. Norré ME. Evaluation of a screening procedure by hot water caloric test. Acta Otorhinolaryngol Belg. 1975;29:558-564.

6. Dayal VS, Farkashidy J, Kuzin B. Clinical evaluation of the hot caloric test as screening procedure. Laryngoscope. 1973;83(9):1433-1439. 
7. Becker GD. The screening value of monotherm caloric tests. Laryngoscope. 1979;89:311-4.

8. Keith RW, Pensak ML, Katbamna B. Prediction of bithermal caloric response from monothermal stimulation. Otolaryngol Head Neck Surg. 1991;104(4):499-502.

9. Jongkees LB, Maas JP, Philippsen AJ. Clinical nystagmography. Pract. Otorhinolaryngol (Basel). 1962;24:65-93.

10. A. Sameh Farid, Shereen M, El-Abd, Maha H, AbouElew. Monothermal caloric test its value in assessment of vestibular function. International Congress Series. 2003;1240:1319-24.

11. Mor R, Fragoso M, Taguchi CK, Figueiredo JFFR. Vestibulometria \& Fonoaudiologia: como realizar e interpretar. São Paulo: Lovise; 2001. p.186.

12. Jacobson GP, Newman CW. Background and technique of caloric testing. In: Jacobson GP, Newman CW, Kartush JM. Handbook of balance function testing. Singular Publishing Group: San Diego-London. 1997.

13. Jacobson G, Newman C, Peterson E. Intermpretation and usefulness of caloric testing. In:Jacobson G, Newman C, Kartush J, eds. Handbook of balance testing. St louis, Mo: mosby-Year Book, 1993:193-233.

14. Jacobson GP, Calder JA, Rupp KA, Shepherd VON, Newman GW. Reapraisal of the monothermal warm caloric screening test. Ann Otol Rhinol Laryngol. 1995;104:942-4.

15. Enticott JC, Dowell RC, O'Leary SJ. A comparison of the monothermal and bithermal caloric tests. J Vestib Res. 2003;13(2-3):113-9.
16. Méndez Colunga JC, Alvarez Méndez JC, Carreño Villarreal JM, Alvarez Zapico MJ, Manrique Estrada C, Fernández Alvarez ML, et al. Neonatal hearing loss screening: our results three years after starting the program. Acta Otorrinolaringol Esp. 2005;56(2):55-8.

17. Selimoglu E. Aminoglycoside-induced ototoxicity. Curr Pharm Des. 2007;13(1):119-26.

18. Buszman E, Wrzesniok D, Matusinski B. Ototoxic drugs. I. Aminoglycoside antibiotics. Wiad Lek. 2003;56(5-6):254-9.

19. Jacobson GP, Means ED. Efficacy of a monothermal warm water caloric screening test. Ann Otol Rhinol Laryngol. 1985;94(4pt 1):377-81.

20. Fitzgerald G, Hallpike CS. Studies in human vestibular function I: observations on the directional preponderance of caloric nystagmus resulting from cerebral lesions. Brain 1942;62(part 2):115-37

21. Gonçalves, Denise Utsch; Felipe, Lilian; Lima, Tânia Mara Assis. Interpretação e utilidade da prova calórica. Rev. Bras. Otorrinolaringol. 2008; 74(3): 440-446.

22. McGee M. Electronystagmography in peripheral lesions. Ear Hear 1986;7(3):167-75.

23. Eviatar A, Wassertheil S. The clinical significance of directional preponderance concluded by electronystagmography. J Laryngol Otol 1971;85(4):355-67.

24. Coats AC. Directional preponderance and unilateral weakness as observed in the electronystagmographic examination. Ann Otol Rhinol Otolaryngol 1965;74(3):655-68. 